\title{
CONSTITUTIONAL DUTY TO ENSURE SECURITY BY THE ADMINISTRATION IN POLAND
}

\begin{abstract}
The purpose of this article is to present conclusions from the analysis of the essence and significance of public tasks and constitutional principles that should guide the imposition of these tasks on public and private entities. Due to the relatively wide context of action in the public sphere, these considerations are limited to the sphere of protection and ensuring security. Tasks in this area are subject to high specificity, therefore the purpose of the analysis is to indicate different factors and conditions affecting the shape of security administration. The method of analysis was used as the principal method of the researcher. Critical analysis was used to determine the importance of public tasks and determine their scope in the sphere of security. System analysis allowed explaining the current conditions of the security administration. A comparative legal and legal analysis covered the provisions of the constitution and legal acts regarding the functioning of administration and allowed to give appropriate directions for their interpretation. In order to make the necessary generalizations, the synthesis method was also used.
\end{abstract}

Keywords: public tasks, security administration, security management.

\section{ADMINISTRATION AS THE IMPLEMENTER OF STATE TASKS}

The modern state should effectively fulfill its ministerial role towards all citizens. It does so primarily through public administration units, it can also act through local government or non-public entities, transferring part of its public tasks to them. In the modern state satisfying the needs of citizens, both collective and individual ones, belongs primarily to public administration. In fulfilling the tasks of protecting and ensuring the security of the entire state community, it also plays a leading role (Niewiadomski, 2010; Stahl, 2019; Zimmermann, 2018).

The Constitution and statutory provisions not only confirm the division of responsibilities between individual public administration bodies, but also specify and list them. A deeper analysis of issues related to security ensures that public administration bodies have the necessary legal instruments to act in this regard. There is a whole system that can be called a security administration that guarantees the existence of specialized bodies with the right tools and instruments to prevent security threats.

\footnotetext{
${ }^{1}$ Marta Pomykała, DSc, PhD, Associate Prof., prof. PRz, Rzeszów University of Technology, Faculty of Management, Department of Law and Administration, ul. Powstańców Warszawy 12, 35-959 Rzeszów; e-mail: mpomykal@ @rz.edu.pl. ORCID: 0000-0002-2557-1876.
} 
Tasks in the field of ensuring security reflect one of the most important goals of the state which is to protect individual citizens and the entire community against threats to public life. It should be emphasized that these tasks are also of an original nature. Regardless of how the role of the state is perceived, they are one of the basic human needs - the need for security.

By undertaking its tasks, public administration carries out the basic functions of the state. W. Szostak states that the functions of the state are tasks constantly carried out by the state, remaining in a specific relation to the objectives adopted by the state apparatus - on the one hand, and to the needs (interests) of the society - on the other one (Szostak, 1997). Therefore, these are certain types of state activity undertaken in specific areas of public life. A. Łopatka emphasizes that the content of individual functions depends on the ruling group, the national interests pursued by the state, and the situation of the given state in the international community. It also rightly indicates that the state in various periods of development, depending on historical circumstances or its geographical location, simultaneously performs many functions. The intensity of the state's activity in particular spheres of social life is variable, sometimes it is more intense, sometimes less (Łopatka, 2005). The separation of these spheres is the basis for the separation of the functions of the state (Zieliński, 2006).

The subject scope of the tasks of the state depends on the understanding of the role of the state in social life and could be understood differently at various stages of historical development. In the modern era, views on the role of the state in social life are expressed under two opposing concepts. The first of these - the concept of the liberal state - recognizes that the state should refrain from any interference in various areas of social life, and the state's tasks are reduced to protecting the interests of the individual, safeguarding his personal inviolability and property. State interventions should be moderate and concern separated social areas and be limited to overcoming social tensions, eliminating sharp social contradictions and effectively implementing social reforms. This perception of the state is called the role of "night watchman" (Seidler, Groszyk, Pieniążęk, 2008). The second concept, called state interventionism, assumes the state's interference in various areas of social life, in particular in ensuring law and order, satisfying the need for security, as well as in the economy and social affairs. All this is to be carried out in the interests of general social development. The scope of state intervention may be narrower or wider and may include a smaller or larger range of matters, all depending on the adopted detailed concepts. The essence of this idea is to emphasize the role of the state as a regulator and coordinator of all social relations (Seidler, Groszyk, Pieniążęk, 2008). Ensuring security, order, stability and stability, however, always appears in the first place of the realized goals of the state, requiring the intervention of its organs, regardless of the perception of the role of the state, regardless of the stage of society's development, regardless of the political system, and accepted values. Of all the tasks of public administration, it takes priority.

It should be clearly stated that the tasks of public administration are the ones of the state itself (Leoński, 2010), which, because of the function of public administration, always fall into the catalog of public tasks. They are determined by the revealed needs and interests of society (both as individuals and as social groups) (Korybski, 2010). At particular stages of the state's development, current tasks are formulated to implement current socio-political goals. The contemporary catalog of tasks may therefore differ from the catalog formulated by the state in previous eras. Some tasks the state invariably implements, some become outdated and subject to elimination, while others only change their character, taking on a different priority. E. Knosala points out that the catalog of public administration tasks has 
been growing steadily. There is also no doubt that the reorientation of the state's goals entails changes in the tasks aimed at achieving them (Knosala, 2006). Current tasks must serve the implementation of current goals and be necessary to achieve them.

The need for security in the current world is quite strongly emphasized and is high in the hierarchy of all social needs. Therefore, it seems that the catalog of public administration tasks in this area will certainly not be significantly reduced in the near future. However, the opposite situation may occur - this catalog will expand. The reasons for this state of affairs should be seen in the emergence of new threats arising from the development of technical civilization and the information society. New threats create new areas of activity for administration, especially those specialized in the protection of communication security, information security and energy security (Chochowski, 2014). Threats and pathologies known today also change their face under the influence of current social, technical or political conditions. Such evolution requires setting new goals for the state and its organs, defining current tasks and indicating appropriate measures for their effective implementation. As an example, it is worth pointing out the need to engage in closer international cooperation to counter terrorism, organized crime and computer crime. It is worth emphasizing that the variability of security threats in the modern world implies the need to regularly verify the tasks of public administration and constantly adapt their catalog to current needs (Pomykała, 2015).

\section{ENSURING SECURITY AS CONSTITUTIONAL TASKS OF PUBLIC ADMINISTRATION}

Tasks of public administration (including tasks in the field of ensuring security) as tasks of the state are formulated in the highest-ranking regulations, i.e. in the constitution and laws. They define the organization of tasks performed, indicating the competences and properties of specific organizational units of public administration, as well as the procedures for performing tasks. According to J. Wyporska-Frankiewicz, the tasks of administration are a derivative of constitutionally defined obligations of the state or constitutionally defined rights of citizens to a specific activity of the state. It is the obligations of the state mentioned in the constitution regarding various spheres of activity that are the basis for the statutory definition of the tasks of individual public administration entities (Wyporska-Frankiewicz, 2010).

The Constitution can, therefore, be regarded as a kind of stabilizer of the tasks of public administration. It should set boundaries in defining public tasks, limiting the scope of the legislator's and administrative bodies' freedom in determining public tasks. It also translates into boundaries in the selection of tasks and the principles of their implementation. The determinants of the border are both constitutionally defined state goals as well as the principles and values contained in the constitution. In the absence of such a border, public tasks of the administration could be shaped quite freely by the executive, and this should not be considered at all in the rule of law (Błaś, Boć, Jeżewski, 2004).

The Constitution directly defines only part of the tasks of public administration, since calculating their full catalog in this way is obviously not intentional or possible. In the sphere of security, where for the effectiveness and efficiency of activities it is necessary to constantly update tasks, this is particularly justified (Wiśniewski, 2013). The constitution, as a fundamental act, does not seem appropriate for this purpose. The statutory regulation, on the other hand, allows the legislative authority to interfere in the goals and principles of 
the administrative authority by setting ongoing tasks according to identified socio-political needs.

In the current Constitution of the Republic of Poland, an example of a direct definition of administrative tasks in the field of security is Art. 146 (4), which enumerates the competences of the Council of Ministers as the body of executive power, while in point 7 obliges the Council of Ministers to ensure internal security of the state and public order. Findings of the administration's tasks can be found in regulations specifying the objectives and functions of the state and the rights of citizens regarding security-related issues. Such provisions are the basis for specific competences and tasks of administrative bodies, which should, however, be sought in the provisions of the Constitution establishing these bodies or in the provisions of special acts.

In art. 5 of the Constitution of the Republic of Poland (Constitution, 1997), the main directions and objectives of the state were established, and one of them was the assurance of citizen security. Article 26, specifying the general wording of Article 5, indicates the Armed Forces as the entity which, in addition to protecting the independence of the state, the integrity of its territory, and inviolability of its borders, is intended to ensure state security. Article 74 obliges public authorities to pursue policies ensuring ecological security for both present and future generations. Article 76, on the other hand, imposes an obligation to protect the rights of consumers, users and tenants against threats to their health, privacy and security, and unfair market practices. Analyzing the above provisions of the Constitution of the Republic of Poland, it can be stated that the tasks of the administration in the field of security protection to a small extent result from the Basic Law. Rather, these are fragmentary provisions, relating to ensuring security in some areas particularly relevant to society at the current stage of its development, most of them define only the area of activity of state organs, leaving the determination of specific competences and means of their implementation to specific regulations.

\section{ENSURING SECURITY AS A TASK OF PUBLIC ADMINISTRATION}

For the most part, public administration tasks are determined by laws and executive acts issued on their basis. It can even be seen that the focus of legal regulation is shifting more and more to laws, and the statutory delegations placed in them open the possibility of deciding on the scope of these tasks by public administration bodies that will implement them. This situation also includes the tasks in the field of ensuring and protecting security. It should be emphasized, however, that in the case of statutory regulations, freedom in shaping tasks is not unlimited and does not belong solely to the legislative authority. "Unless the constitution explicitly defines the tasks of public administration, the boundaries in the choice of tasks, the manner in which they are implemented, constitute constitutionally defined state goals, as well as the principles and values contained in the constitution" (Błaś, Boć, Jeżewski, 2004). The tasks detached from constitutional principles and values would arise from political demands, economic programs, election promises and would be the subject of pre-election tenders. That is why the Constitution contains more or less specific administrative tasks (M. Karpiuk, 2013).

A. Błaś emphasizes that "the administrative authority derives its powers to perform public tasks from legal norms which it does not itself” (Błaś, Boć, Jeżewski, 2004). Therefore, he is not a disposer of the tasks he carries out. There is also no freedom in determining the scope of the task being carried out. The administration cannot free itself from tasks by 
reducing them, suspending their performance or transferring them without any explicit instruction to other entities. Therefore, the administration's tasks can be described as the obligation to undertake active activity by the entity entrusted with it. They have the nature of legal obligations, and their non-performance gives rise to legal liability. The administration may, however, have some freedom as to how the task will be carried out, however, its boundaries are always drawn in constitutional or statutory acts, and never in the norms of law it makes.

Normative establishment of administration tasks means that the administration cannot avoid accepting these tasks for implementation. The provision of law usually simultaneously specifies the actions that the administrative body should take in a given case. By making these actions, he makes use of his right. The scope of powers and duties assigned to the administrative body is referred to as the competence of that body. As J. Zimmermann states, competence is' a possibility (right) and at the same time an obligation to use a specific form (forms of action) belonging to administrative activities. "(...) Having competences in a given scope, the administrative body is obliged to use it, and not fulfilling this obligation is tantamount to the so-called inaction of the body. Such defined competence of an administrative body should be distinguished from its tasks, which are also defined by law, but do not relate to a specific action and the obligation to perform a specific action, but relate to the more general purpose to be achieved by the body, using all its competences" (Zimmermann, 2018). Competency regulations are usually found in specific laws regulating individual areas of public administration. In the case of security, these will be provisions regulating the tasks and forms of activity of entities responsible for ensuring, maintaining and protecting security.

Security tasks, regardless of whether they are performed by public administration entities or non-public entities, should be included in the category of public tasks (Pieprzny, 2007; Pieprzny, 2008). The concept of public tasks is considered one of the most difficult categories in the study of administrative law. According to R. Stasikowski, "public tasks are those which the legislator and public administration entities are interested in performing due to certain social goals (values) valid in a given place and time, as part of constitutional norms determining the state system" (Stasikowski, 2009). As M. Stahl rightly argues: "public tasks are, as a rule, assigned to the state. It decides, under the influence of political factors, which tasks it will carry out by its organs on an exclusive basis, which can be (and even must be) delegated to other public authorities, and which can also be performed by non-public entities" (Stahl, 2007). S. Biernat, on the other hand, notes that the audience of tasks is primarily demonstrated by the fact that the state or local government is legally responsible for their implementation. At the same time, it is not necessary for the performance of tasks to take place within the organizational structures of public administration, or even the structures of the state or local government (Biernat, 1994).

Public tasks are always the legal obligations of the state and public entities in a legally defined scope in a permanent, continuous, uninterrupted manner, ensuring universal access on a non-commercial basis. Nowadays, the sphere of tasks considered solely state-owned is increasing, and therefore more and more tasks are transferred for implementation to other public entities (local government) and even non-public entities. However, protecting and ensuring the security of citizens is little affected by this trend (Knosala, 2006). This is due to the need for quite frequent use of state coercion in this case, usually reserved for public entities. In this way, most of the tasks from the sphere of security remain in the hands of public administration bodies, especially government administration. 
The tasks of the state referred to as administrative are divided between individual entities performing the role of public administration in the state. Appropriate division is aimed at ensuring their effective implementation (Wyporska-Frankiewicz, 2010). The complexity of today's state organizations and their activity on many levels allows to see a number of detailed functions to be fulfilled, and in addition to each of them to create complex task systems. Increasing the number of tasks results in the creation of new administrative units, because the existing ones become inefficient. Taking into account the multiplicity and diversity of administrative tasks, it is possible to create independent groups of entities within public administration structures, responsible for the implementation of more specific tasks. In this way, within the public administration, security administration can be distinguished as a specific group of entities with a properly adapted organizational structure, as well as equipped with an appropriate set of measures.

\section{CONCLUSIONS}

Public tasks are the legal obligations of the state in certain areas of public life performed in a permanent, continuous, uninterrupted manner, ensuring universal access on a non-commercial basis. The modern state is taking over more and more tasks, which in this way become public tasks, with public administration being the direct implementer of most of them. However, there is a noticeable tendency to transfer the rights to perform public tasks to non-public entities, which, however, does not affect the nature of the tasks themselves.

Contemporary tasks in the field of protection and ensuring security also change and diversify, and the preoccupation of the state with this group of tasks increases. Security administration is increasingly specialized, creating new units to counteract previously unknown threats. However, the security administration seems to be resistant to task privatization processes, because an important element of action in this sphere is the need to use state coercion, usually reserved for public entities. The main burden of implementing public tasks in the sphere of security protection rests on public entities, including those constituting government administration.

\section{REFERENCES}

Biernat, S. (1994). Prywatyzacja zadań publicznych. Problematyka prawna. Warszawa-Kraków: Wydawnictwo Naukowe PWN

Błaś, A., Boć, J., Jeżewski, J. (2004). Administracja publiczna. Wrocław: Kolonia Limited. Constitution of the J. Republic of Poland of April 2, 1997 (Journal of Laws of 1997, No. 78, item 483, as amended)

Chochowski, K. (2014). Bezpieczeństwo publiczne jako dobro publiczne [in:] Woźniak, M., Pierzchała, E., ed., Dobra publiczne w administracji. Toruń: Wydawnictwo Adam Marszałek.

Karpiuk, M. (2013). Zadania i kompetencje zespolonej administracji rzadowej $w$ sferze bezpieczeństwa narodowego Rzeczypospolitej Polskiej. Aspekty materialne i formalne. Warszawa: Wydawnictwo Akademii Narodowej.

Knosala, E. (2006). Zarys nauki administracji. Warszawa: Wolters Kluwer.

Korybski, A. (2010). Funkcje państwa [in:] Szmulik, B., Żmigrodzki, M., ed., Wprowadzenie do nauki o państw i polityce. Lublin: Wydawnictwo Uniwersytetu Marii Curie-Skłodowskiej.

Leoński, Z. (2010). Nauka administracji. Warszawa: C.H.Beck.

Łopatka, A. (2005). Prawoznawstwo. Warszawa: Iuris. 
Niewiadomski, Z. (2010). Pojęcie administracji publicznej [in:] Hausner, R., Niewiadomski, Z., Wróbel, A., ed., System Prawa Administracyjnego. Instytucje prawa administracyjnego. Warszawa: Wydawnictwo C.H.Beck, Instytut Nauk Prawnych PAN.

Pieprzny, S. (2008). Administracja bezpieczeństwa i porządku publicznego. Rzeszów: Wydawnictwo Uniwersytetu Rzeszowskiego.

Pieprzny, S. (2007). Ochrona bezpieczeństwa i porządku publicznego w prawie administracyjnym. Rzeszów: Wydawnictwo Uniwersytetu Rzeszowskiego.

Pomykała, M. (2015). Działania planistyczne administracji w systemie bezpieczeństwa wewnętrznego państwa. Rzeszów: Oficyna Wydawnicza Politechniki Rzeszowskiej.

Seidler, G.L., Groszyk, H., Pieniążek, A. (2008). Wprowadzenie do nauki o państwie i prawie. Lublin: Wydawnictwo Uniwersytetu Marii Curie-Skłodowskiej.

Stahl, M. (2007). Cele publiczne i zadania publiczne [in:] Zimmermann, J., ed., Koncepcja systemu prawa administracyjnego. Warszawa: Wolters Kluwer Polska.

Stahl, M. (2019). Pojęcie administracji publicznej, jej cechy i funkcje [in:] Stahl, M., ed., Prawo administracyjne. Pojęcia, instytucje, zasady w teorii i orzecznictwie. Warszawa.

Stasikowski, R. (2009). Funkcja regulacyjna administracji publicznej. Studium z zakresu nauki prawa administracyjnego oraz nauki administracji, Bydgoszcz-Katowice: Wyd. Branta.

Szostak W. (1997). Wspótczesne teorie państwa. Kraków: Księgarnia Akademicka.

Wiśniewski, B. (2013). System bezpieczeństwa państwa. Konteksty teoretyczne i praktyczne. Szczytno: WSPol.

Wyporska-Frankiewicz, J. (2010). Publicznoprawne formy działania administracji o charakterze dwustronnym. Warszawa: Wolters Kluwer Business.

Zieliński, E. (2006). Nauka o państwie i polityce. Warszawa: Elipsa.

Zimmermann, J. (2018). Prawo administracyjne. Warszawa: Wolters Kluwer Polska.

DOI: $10.7862 /$ rz.2019.mmr.22

The text was submitted to the editorial office: October 2019.

The text was accepted for publication: October 2019. 
